EXPERIMENTAL STUDY

\title{
Lithium stimulates proliferation in cultured thyrocytes by activating Wnt/ $\beta$-catenin signalling
}

\author{
A S Rao, N Kremenevskaja, J Resch and G Brabant \\ Department of Gastroenterology, Hepatology and Endocrinology, Medical School Hannover, Carl Neuberg Strasse 1, D-30625 Hannover, Germany
}

(Correspondence should be addressed to G Brabant; Email: brabant.georg@mh-hannover.de)

\begin{abstract}
Background: Lithium, clinically used in the treatment of bipolar disorders, is well known to induce thyroid growth. However, the mechanism involved is only incompletely characterized. Although it is conventionally believed that thyroid proliferation depends on the thyroid-stimulating hormone (TSH)/cAMP/cAMPresponseelementbinding protein (CREB) pathway, recent data indicate that Wnt/ $\beta$-catenin signalling may be of critical importance. In other cell types lithium activates canonical Wnt signalling by GSK-3 $\beta$ inhibition, which in turn stabilizes cytosolic free $\beta$-catenin. Here we investigated the potential modulation of $W n t / \beta$-catenin signalling under lithium treatment in primary and neoplastic human thyrocytes.

Methods: Primary (S18) and neoplastic (NPA, FTC133) thyrocytes treated with and without LiCl were analysed using Western blotting, immunoprecipitation, reporter-gene assay, MTT proliferation assay and transfection studies.

Results: LiCl dose-dependently inhibited GSK-3 $\beta$, stabilized free $\beta$-catenin and inhibited $\beta$-catenin degradation. Furthermore, $\mathrm{LiCl}$ altered the assembly of adherens junction by upregulating the E-cadherin repressor, Snail, and downregulated E-cadherin expression. At a dose of $5 \mathrm{mM}$, LiCl significantly increased the proliferative potency of thyrocytes, which appeared to be mediated by $\beta$-catenin, since nuclear $\beta$-catenin stimulated T-cell factor/lymphoid enhancer factor (TCF/LEF)-mediated transcription and upregulated downstream targets like cyclin D1. To characterize the specificity of Wnt/ $\beta$-catenin-driven thyrocyte proliferation, we transfected primary thyrocytes and FTC133 cells with dominant negative TCF4 to block Wnt-dependent pathways or with dominant negative CREB to inhibit the TSH/cAMP cascade. In cells transfected with dominant negative CREB lithium-stimulated proliferation was unchanged whereas blocking Wnt/ $\beta$-catenin by dominant negative TCF4 reduced proliferation by approx. $50 \%$.

Conclusion: Our data indicate that Wnt/ $\beta$-catenin signalling is of major importance in the control of lithium-dependent thyrocyte proliferation.
\end{abstract}

European Journal of Endocrinology 153 929-938

\section{Introduction}

Lithium is used in the management and prophylaxis of bipolar psychiatric disorders. As a side-effect lithium causes nodular growth and goitre in a subset of patients even when euthyroidism is maintained by L-thyroxine treatment $(1,2)$. The underlying mechanism is unclear but may be based on a direct effect as in vitro studies by Gaberscek et al. (3) in FRTL-5 cells indicate an increased proliferation with low-dose lithium. Proliferation and differentiation of cultured thyroid cells is regulated by a number of growth factors. Signalling through the thyroid-stimulating hormone (TSH)/cAMP/protein kinase A (PKA)/cAMPresponseelementbinding protein (CREB) and through insulinlike growth factor I (IGF-I)-dependent pathways have been regarded as major stimulatory factors in the control of thyrocyte proliferation and differentiation (4). TSH withdrawal induces growth arrest, but addition of the hormone to quiescent cells stimulates entry of the cells into the $S$ phase (5). This concept was recently challenged by studies with TSH receptor-knockout mice that develop normal-sized thyroid despite inactivation of the TSH cascade (6). Moreover, in thyroid carcinoma TSH-independent growth is most frequently observed as reduced or missing expression of the TSH receptor, which implies a decreased responsiveness to TSH (7).

Recent findings on growth-promoting effects of $\beta$-catenin and the Wnt signalling pathway provide an alternative explanation (8). Lithium is capable of inhibiting glycogen synthase kinase $\beta$ (GSK-3 $\beta$ ), a phosphorylating enzyme operative in the degradation 
of free $\beta$-catenin, which mimics the effects of Wnt signalling activation $(8,9)$. Activation of canonical Wnt signalling stabilizes cytosolic $\beta$-catenin, which translocates to the nucleus, stimulates T-cell factor/lymphoid enhancer factor (TCF/LEF) and target genes such as cyclin D1. We showed recently $(10,11)$ that this mechanism, important for many cell types (1214 ), is operative in the thyroid. One of the target genes, cyclin D1, is increased, and serves as a central regulator of the cell cycle and cell proliferation (1519). Lithium inhibits GSK-3 $\beta$ and may thus mimic a functional activation of the canonical Wnt signalling pathway, increase the relative abundance of intracellular cyclin D1 levels and confer a proliferative advantage to the cell. Additionally, $\beta$-catenin binds to E-cadherin, a transmembrane protein, to form the adherens junction and mediates cell-cell adhesion. Loss of E-cadherin leads to an impairment of the cadherin-catenin complex at the cell junction which may contribute to an increased pool of free $\beta$-catenin $(13,20,21)$.

The aim of the present study was to investigate the potential role of $\mathrm{Wnt} / \beta$-catenin signalling in the regulation of growth and proliferation of primary and neoplastic thyrocytes. Using lithium as a tool to activate Wnt/ $\beta$-catenin signalling, we investigated whether its modulation may serve as a mechanism to regulate thyrocyte proliferation.

\section{Materials and methods}

\section{Primary thyroid culture and cell lines}

Primary thyroid culture was derived from thyroid tissues (nodular goitre, normal tissue adjacent to a thyroid carcinoma) obtained from patients who underwent surgery at the surgical department. All patients gave informed consent. Briefly, the thyroid was cut into small pieces, washed three times in cold PBS (20-fold volume, centrifugation at $70 \boldsymbol{g}$ for $5 \mathrm{~min}$ ), resuspended in $40 \mathrm{ml}$ PBS (without calcium and magnesium) containing $5 \mathrm{mg} / \mathrm{ml}$ dispase II, and incubated at $37^{\circ} \mathrm{C}$ for $30 \mathrm{~min}$. This was followed by centrifugation at $70 \boldsymbol{g}$ for $5 \mathrm{~min}$. Incubations were repeated seven times with alternate use of collagenase $(1 \mathrm{~g} / \mathrm{l})$ and dispase, finally yielding thyroid follicles and single cells. Cells were washed in RPMI 1640 containing $20 \mathrm{mmol} / \mathrm{l}$ HEPES, $10 \%$ foetal calf serum (FCS), $100 \mathrm{U} / \mathrm{ml}$ penicillin $\mathrm{G}$ and $100 \mathrm{mg} / \mathrm{l}$ streptomycin, and transferred to culture flasks. Human thyroid cells were propagated in Coon's $6 \mathrm{H}$ medium containing $10 \% \mathrm{FCS}, 100 \mathrm{U} / \mathrm{ml}$ penicillin and $100 \mathrm{mg} / \mathrm{l}$ streptomycin in a humidified $5 \% \mathrm{CO}_{2}$ incubator at $37^{\circ} \mathrm{C}$.

NPA and FTC133 are cell lines derived from papillary and follicular thyroid carcinoma, respectively. NPA cells were grown in RPMI 1640 medium (with HEPES and L-glutamine; PAA Laboratories, Cölbe, Germany) supplemented with 10\% FCS (PAA Laboratories, Linz, Austria), $100 \mu \mathrm{g} / \mathrm{ml}$ streptomycin and $100 \mathrm{U} / \mathrm{ml}$ penicillin in a humidified atmosphere with 5\% $\mathrm{CO}_{2}$. The FTC133 cell line was similarly maintained in Dulbecco's modified Eagle's medium (DMEM).

\section{Chemicals and reagents}

Anti- $\beta$-catenin, anti-GSK- $3 \beta$ and anti-E-cadherin monoclonal antibodies (mAbs) were purchased from BD Transduction Laboratories (Heidelberg, Germany); $\alpha$-tubulin $\mathrm{mAb}$ and anti-cyclin D1 polyclonal rabbit antibody from Santa Cruz Biotechnology (Santa Cruz, CA, USA); anti-snail mAb was from Chemicon International (Hofheim, Germany); alkaline phosphatase-conjugated goat anti-rabbit IgG secondary antibody and CSPD $^{\circledR}$ chemiluminescence reagent were from Roche (Mannheim, Germany); alkaline phosphatase-conjugated sheep anti-mouse IgG secondary antibodies were from Dianova (Hamburg, Germany). All other reagents were purshased from Sigma (Taufkirchen, Germany). Stock solutions of LiCl, obtained from Calbiochem (Schwalbach, Germany), were prepared as $1 \mathrm{mM}$ in DMSO and stored at $4^{\circ} \mathrm{C}$ for future use.

\section{MTT cell proliferation and viability assay}

An MTT (3(4,5dimethylthiazol2yl)2,5diphenyl2Htetrazolium bromide) proliferation assay was carried out as previously described (22). Growth experiments were performed in a 24-well plate in $5 \mathrm{H}$ medium without TSH. Cells at $85-100 \%$ confluence were trypsinized and $10^{4}-10^{5}$ cells/well were seeded and maintained in $200 \mu \mathrm{l} 5 \mathrm{H}$ medium in a humidified incubator. After $24 \mathrm{~h}$, the cells were incubated with $5 \mathrm{mM} \mathrm{LiCl}$ and colorimetric MTT (Sigma) proliferation assays were performed at 0,12 and $24 \mathrm{~h}$ after treatment. MTT $(400 \mu \mathrm{g} / \mathrm{ml})$ was added to each well, incubated for $3 \mathrm{~h}$ and was solubilized with $0.04 \mathrm{M} \mathrm{HCl}$ /iso-propanol for $1 \mathrm{~h}$. The optical density (OD) was determined using a spectrophotometer (Ultrospec K; Biochrom, Berlin, Germany) at a wavelength of $570 \mathrm{~nm}$. The experiment was repeated three times in triplicate.

\section{[ H]Thymidine-incorporation assays}

The cells were plated out in flat-bottomed 96-well plates (Corning Costar, Cambridge, MA, USA) at a density of $2 \times 10^{2}$ cells/well for $24 \mathrm{~h}$ in standard tissue-culture medium. After a $24 \mathrm{~h}$ incubation at $37^{\circ} \mathrm{C}$, the cells in the 96 -well plates were subjected to $\mathrm{LiCl}(5 \mathrm{mM})$. During the last $18 \mathrm{~h}$ the cells were incubated with $\left[{ }^{3} \mathrm{H}\right]$ thymidine $(0.5 \mu \mathrm{Ci} /$ well $)$ and after harvesting the incorporated radioactivity (c.p.m.), proliferation of the cells was measured in a $\beta$-counter (LKB, Wallah, Germany).

\section{Cellular and nuclear extracts}

All cell lines were grown in $100 \mathrm{~mm}$ culture dishes (Falcon, Heidelberg, Germany) at $85-100 \%$ confluence 
and were incubated with or without different concentrations of $\mathrm{LiCl}(0,10 \mu \mathrm{M}, 100 \mu \mathrm{M}, 1 \mathrm{mM}, 2 \mathrm{mM}$, $5 \mathrm{mM}, 10 \mathrm{mM}, 20 \mathrm{mM}$ ) for $0,6,12$ and $24 \mathrm{~h}$. Cells were lysed in $100 \mu$ l lysis buffer $(50 \mathrm{mM}$ HEPES, pH 7.4, $150 \mathrm{mM} \mathrm{NaCl}, 10 \%$ glycerol, $1 \mathrm{mM}$ EDTA, $1 \mathrm{mM}$ sodium orthovandate, $10 \mathrm{mM}$ sodium pyrophosphate, $100 \mathrm{mM} \mathrm{NaF}, 1 \%$ Triton X-100, $10 \mu \mathrm{g} / \mathrm{ml}$ leupeptin, $10 \mathrm{U} / \mathrm{ml}$ aprotinin and $1 \mathrm{mM}$ phenylmethylsulfonyl fluoride). To analyse $\beta$-catenin in nuclear fractions, intact nuclei were prepared from exponentially growing cells by scraping cells into nuclei isolation buffer $(100 \mathrm{mM}$ $\mathrm{NaCl}, 10 \mathrm{mM}$ Tris $/ \mathrm{HCl}, 5 \mathrm{mM}$ sodium butyrate, $10 \mathrm{mM}$ iodoacetamide, $0.1 \%$ Nonidet P-40 and phosphatase inhibitors, as described above). Aliquots of these samples were fractionated by $7.5 \%$ SDS/PAGE, electrotransferred to nitrocellulose membranes and analysed by Western blotting.

\section{Immunoprecipitation and Western blot analysis}

Phosphorylation of $\beta$-catenin or GSK-3 $\beta$ was detected by performing immunoprecipitation with the antibody to $\beta$-catenin or GSK-3 $\beta$ followed by immunoblotting for $\beta$-cateninphosphoserine ${ }^{37}$ or phosphoserine $^{9}$ GSK-3ßas described previously (10). For Western blot analysis, proteins $(10 \mu \mathrm{g} /$ lane $)$ were resolved in $7.5 \%$ SDS-PAGE and electrotransferred to a nitrocellulose membrane (Millipore, Schwalbach, Germany) using standard procedures. After blocking with 4\% nonfat dry milk in TBS-T buffer (20 mM Tris-HCl, pH 7.4, $150 \mathrm{mM} \mathrm{NaCl}, 0.1 \%$ Tween-20), the blots were probed with monoclonal mouse primary antibodies against $\beta$-catenin, $\beta$-catenin phosphorylated at Ser37 (phospho-Ser-37- $\beta$-catenin), GSK-3 $\beta$, GSK-3 $\beta$ phosphorylated at Ser-9 (phospho-Ser-9-GSK-3 $\beta$ ), E-cadherin or snail, or rabbit polyclonal antibody against cyclin D1. The blots were then reacted with a secondary alkaline phosphate-conjugated anti-mouse antibodies, followed by detection of the proteins with CSPD $^{\circledR}$ chemiluminescence reagent. Autoradiograph films were scanned by means of Gel Documentation Systems (Gel Doc $2000^{\text {TM }}$; Bio-Rad) to obtain integrated densitometric values. Density of the immunoreactive bands were assessed and correlated to the relative amount of immunoreactive protein using Quantitiy One* Quantitation software (Bio-Rad). To calculate the unphosphorylated fraction of GSK-3 $\beta$ the following formula was used:

Unphosphorylated GSK-3 $\beta$

$$
=\frac{\text { Total GSK-3 } \beta-\text { phospho-Ser-9-Gsk-3 } \beta}{\text { Total GSK-3 } \beta} \times 100
$$

A dose-dependent curve for lithium was constructed where the percentage ratio of the unphosphorylated active GSK-3 $\beta$ was plotted against the concentrations of lithium between 0 and $20 \mathrm{mM}$.

\section{Immunofluorescence and confocal microscopy}

In six-well plates, S18 primary thyrocytes were seeded on 12-mm diameter glass coverslips with or without lithium $(5 \mathrm{mM})$ and grown to $50 \%$ confluence in RPMI-1640 medium supplemented with 10\% FCS and $1 \%$ penicillin/streptomycin. The cells were fixed in $4 \%$ paraformaldehyde for $20 \mathrm{~min}$ and permeabilized with $0.1 \%$ Triton X-100 (Fluka Sigma-Aldrich Chemie, Deisenhofen, Germany) in PBS for $5 \mathrm{~min}$ at room temperature. Incubations with primary antibodies (mouse anti- $\beta$-catenin mAb, mouse anti-E-cadherin $\mathrm{mAb}$, rabbit polyclonal cyclin D1 antibody) were followed by sheep anti-mouse FITC (fluorescein isothiocyanate)- or goat anti-rabbit TRITC (tetramethylrhodamine ßisothiocyanate; Sigma)-conjugated secondary antibodies for $1 \mathrm{~h}$ at room temperature. Finally the cells were embedded in Vectashield mounting medium (Vector Laboratories, Burlingame, CA, USA) and viewed by confocal laser scanning microscopy (Leica Inverted TCS; Leica Microsystems, Heidelberg, Germany).

\section{Stable transfections}

Stable transfections with dominant negative TCF4 (dnTCF) and dominant negative CREB (dnCREB) was performed on the follicular thyroid cancer cell line FTC133 as described previously (10). Briefly, FTC133 cells were maintained in DMEM supplemented with penicillin/streptomycin and 5\% FCS. Cells were seeded 1 day prior to transfection at approximately 50-70\% confluence. The cells were cultured overnight in sixwell dishes and transfected with dnTCF4 (kindly provided by $\mathrm{H}$ Clevers, Utrecht University, Utrecht, The Netherlands) and dnCREB (kindly provided by $\mathrm{C}$ Vinson, National Institutes of Health, Bethesda, MD, USA) using FuGENE 6 transfection reagent (Roche) following the manufacturer's instructions. An appropriate amount of empty vector (pClneo construct) was added in the control well. After 5 days of transient transfection the cells were grown in DMEM supplemented with the presence of selection marker, zeocin (dnTCF4) or G418 (dnCREB) and grown for a further 2 weeks. Single cells were replated on new culture plates and the cells were grown to $80-100 \%$ confluence.

\section{Luciferase reporter-gene assay}

For the detection of Wnt transcriptional activity, luciferase reporter-gene analysis was performed in primary thyrocytes and FTC133 cells with and without $\mathrm{LiCl}$ ( $5 \mathrm{mM})$. The cells were transfected with $1 \mu \mathrm{g}$ TOP Flash or FOP Flash plasmid (Upstate Biotechnology, 
Lake Placid, NY, USA), $1 \mu \mathrm{g}$ pSV $\beta$-galactosidase vector (Promega, Madison, WI, USA) and/or empty vector using Lipofectamine (Roche). Luciferase and $\beta$-galactosidase activities were measured $48 \mathrm{~h}$ after transfection according to standard methods and were used to control of transfection efficiency (Promega).

\section{Statistical analysis}

The results are expressed as means \pm S.D. and statistical analysis was done using Student's $t$-test. Statistical significance was defined as a $P$ value of $<0.05$.

\section{Results}

\section{LiCl activates the Wnt signalling pathway by inhibiting GSK-3 $\beta$ in a dose-dependent manner}

Prior studies with embryological models suggest that $\mathrm{LiCl}$ mimics Wnt/ $\beta$-catenin activation by inhibiting GSK-3 $\beta$ activity through phosphorylation at Ser-9 (8, $9)$. To confirm this effect in the thyroid we investigated the effect of $\mathrm{LiCl}$ on GSK-3 $\beta$ in normal and neoplastic thyrocytes using serum-free conditions (0.1\% FCS). After $24 \mathrm{~h}$ serum deprivation, cells were incubated with $\mathrm{LiCl}(5 \mathrm{mM})$ for $0-24 \mathrm{~h}$. Inhibition of GSK-3 $\beta$ (i.e. GSK-3 $\beta$ Ser-9 phosphorylation) was assessed by immunoblot analysis using a phospho-Ser-9-specific antibody. In control cells derived from normal thyrocytes (S18) or thyroid cancer cell lines (NPA, FTC133) the level of inactive phosphorylated GSK-3 $\beta$ was low whereas exposure to $\mathrm{LiCl}$ dose-dependently increased the inactive, phosphorylated form of
GSK-3 $\beta$ (Fig. 1A). under both sets of conditions total GSK-3 $\beta$ content remained unaltered. Over a range of $1-20 \mathrm{mM} \mathrm{LiCl}$ this effect was dose-dependent. When comparing total and phosporylated fractions of GSK$3 \beta$ by quantitative densitometry following immunoprecipitation on Western blots a dose of $5 \mathrm{mM} \mathrm{LiCl}$ reduced the unphosphorylated active form of GSK-3 $\beta$ by $80-95 \%$ in all cell types tested (Fig. 1B). Moreover, $\mathrm{LiCl}$ (5-20 mM)-induced Ser-9 phosphorylation of GSK-3 $\beta$ seemed to be higher in the primary as compared with the neoplastic thyrocytes (Fig. 1B).

\section{LiCl increases intracellular free $\beta$-catenin levels in thyroid cell lines}

This lithium effect on GSK-3 $\beta$ is reflected in stabilized cytoplasmatic $\beta$-catenin levels. Free $\beta$-catenin levels in total lysates of both the primary (S18) and neoplastic thyrocytes (NPA, FTC133) increased not only in a dosedependent $(0-20 \mathrm{mM})$ but also in a time-dependent $(0-24 \mathrm{~h})$ manner (Fig. 2A and B). Because $\beta$-catenin phosphorylation at Ser-37 is regarded as the target for GSK-3 $\beta$ action we tested the effects of GSK-3 $\beta$ inhibition by lithium by immunoblot analyses using $\beta$-catenin and specific phospho-Ser-37- $\beta$-catenin mAbs. LiCl induced a mild decline in phospho-Ser-37- $\beta$-catenin over a concentration range of $0-20 \mathrm{mM}$ in all cells tested (S18, NPA, FTC133) whereas the total $\beta$-catenin levels increased (Fig. 2A and C). Since our data indicated that $\mathrm{LiCl}$ completely inactivates GSK-3 $\beta$ at higher concentrations between 10 and $20 \mathrm{mM}$ in all cells, the presence of phosphorylated $\beta$-catenin at these doses, even exceeding $10 \mathrm{mM}(10-20 \mathrm{mM})$, was unexpected. However, this observation may be

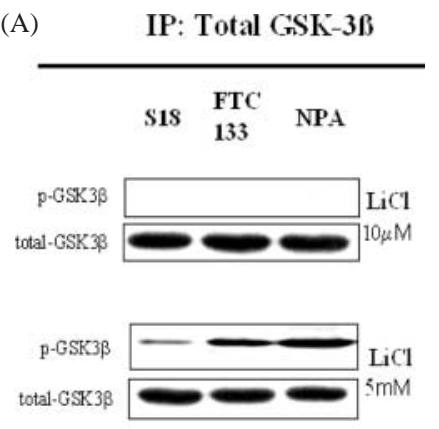

IB : Phospho Ser 9- GSK-3B
(B) Effect of $\mathrm{LiCl}$ on GSK-3 3 phosphorylation

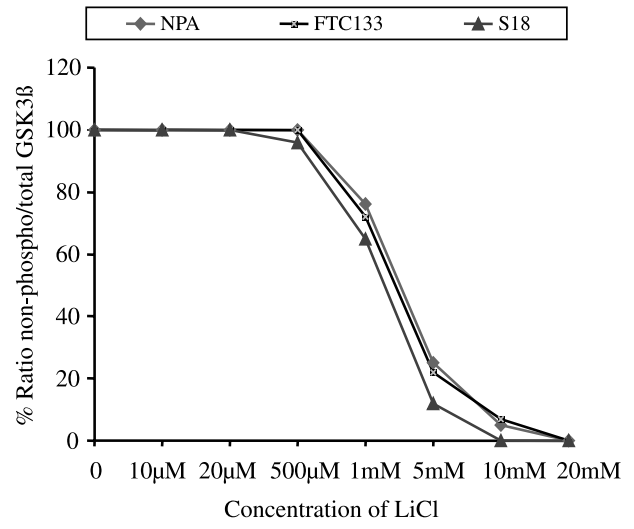

Figure 1 (A) Dose-dependent effects of $\mathrm{LiCl}$ on normal and neoplastic thyrocytes. Total GSK-3 $\beta$ was immunoprecipitated (IP) using a mouse anti-GSK-3 $\beta$ mAb (lower lanes) and immunoblot (IB) analysis was performed using anti-phospho-Ser-9-GSK-3 (upper lanes). Low-dose lithium $(10 \mu \mathrm{M})$ did not inhibit GSK-3 $\beta$ as evidenced by the absence of the phosphorylated inactive form. At $5 \mathrm{mM}$ LiCl, GSK-3 $\beta$ was inactivated in both normal and neoplastic thyrocytes. The total GSK-3 $\beta$ served as the control and remained unchanged. (B) A dose-response curve for lithium was constructed where the percentage ratio of the unphosphorylated active GSK-3 $\beta$ was plotted against the concentrations of lithium between 0 and $20 \mathrm{mM}$. GSK-3 $\beta$ activity was inhibited by more than $80 \%$ in all cells by LiCl in the dose range of $5-10 \mathrm{mM}$.

www.eje-online.org 


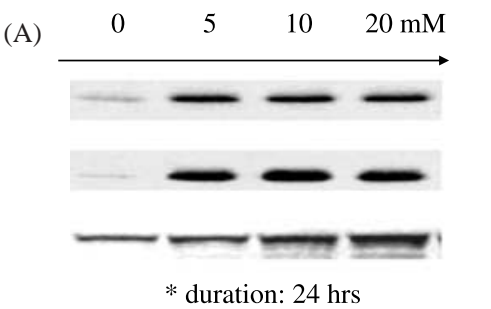

IB: Pan $\beta$-catenin mAb

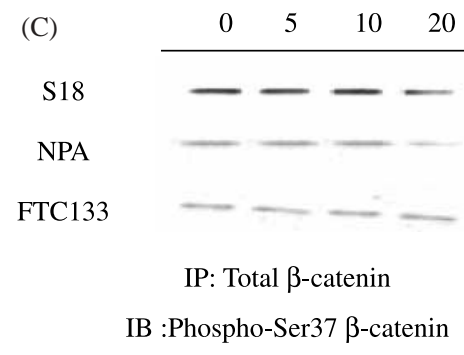

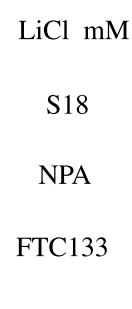

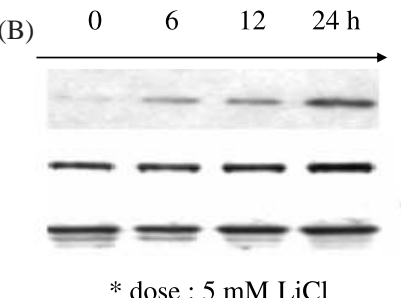

IP: Pan $\beta$-catenin mAb

(D)

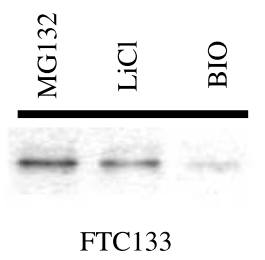

IB :Phospho-Ser37 $\beta$-catenin
Figure 2 Western blot analyses of normal (S18) and neoplastic (NPA, FTC133) thyrocytes to demonstrate dose- $(A)$ and timedependent (B) stabilization of total $\beta$-catenin in total cell lysates. To elucidate the effect of $\mathrm{LiCl}$ on $\beta$-catenin phosphorylation, $\beta$-catenin was immunoprecipitated (IP) using a mouse anti- $\beta$-catenin mAb and immunoblot (IB) analysis was performed using anti-phospho-Ser-37- $\beta$-catenin antibody (C). Differential effects of MG132, $\mathrm{LiCl}$ and $\mathrm{BIO}$ on phospho-Ser-37- $\beta$-catenin levels were compared in FTC133 cells (D). explained by the recent findings of Rice \& Sartorelli (23) indicating an inhibitory effect of lithium on the $20 \mathrm{~S}$ proteasome. To confirm this we used BIO, a specific GSK-3 $\beta$ inhibitor, and MG132, a specific proteasomal

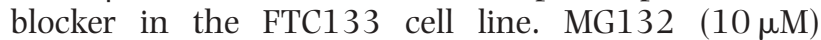
caused an enhanced signal of phospho-Ser-37- $\beta$-catenin, highlighting the importance of a functional proteasomal degradation system in these cells (Fig. 2D). LiCl (20 mM) mirrored the effects of MG132 by stabilizing Ser-37-phosphorylated $\beta$-catenin despite near-total inhibition of GSK-3 $\beta$ (Figs $1 \mathrm{~B}$ and 2D). The GSK-3 $\beta$ activity was completely inhibited by $\mathrm{BIO}$ at a concentration of $100 \mathrm{nM}$ (data not shown). However, at this dose only marginal amounts of Ser-37-phosphorylated $\beta$-catenin were detected (Fig. 2D), which may be explained by an incomplete degradation of $\beta$-catenin after $48 \mathrm{~h}$. Taken together, the differential effects of
$\mathrm{LiCl}$ and BIO on Ser-37-phosphorylated $\beta$-catenin (at doses where GSK-3 $\beta$ activity is inhibited) indicate that $\mathrm{LiCl}$ has inhibitory effects on the proteasome.

\section{Lithium decreases the $\beta$-catenin/E-cadherin binding by decreasing total E-cadherin levels}

To delineate a potential direct effect of lithium on E-cadherin we studied the effect of lithium on E-cadherin regulation. In all E-cadherin-expressing cell lines (S18, FTC133) lithium dose-dependently (1-10 mM) decreased total E-cadherin levels (Fig. 3A) and reduced $\beta$-catenin/E-cadherin binding (Fig. 3B). This process may further increase cytosolic/nuclear accumulation of free $\beta$-catenin. Since NPA did not express endogenous E-cadherin we excluded it from this experiment. Next, we tested whether snail, a potential target of GSK-3 $\beta$, plays
(A) $\mathrm{LiCl}(\mathrm{mM})$

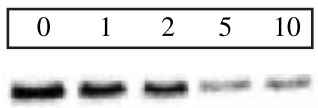

S18

FTC133

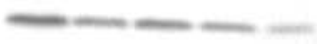

$\mathrm{IB}:$ E-cadherin $\mathrm{mAb}$

(C)

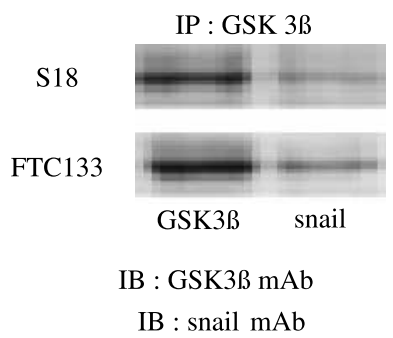

(B) $\mathrm{LiCl}(\mathrm{mM})$

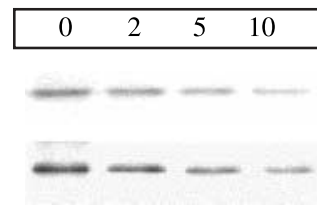

IP: E-cadherin IB: B-catenin $\mathrm{mAb}$

(D)

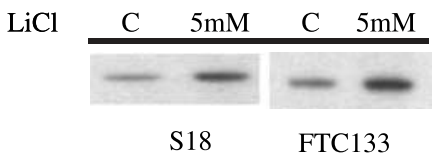

IB : snail mAb
Figure 3 The effect of $\mathrm{LiCl}$ on the E-cadherin. (A) Immunoblot (IB) analyses of Ecadherin expressing primary (S18) and neoplastic (FTC133) thyrocytes to demonstrate dose-dependent loss of $\mathrm{E}$-cadherin in response to $\mathrm{LiCl}$. (B) Effect of $\mathrm{LiCl}$ on the $\beta$-catenin/E-cadherin binding. Immunoprecipitation (IP) was performed employing a $\mathrm{E}$ cadherin $\mathrm{mAb}$ and the associated $\beta$-catenin was detected by immunoblot analyses. (C) Reciprocal co-immunoprecipitation experiments demonstrated a functional interaction between GSK-3 $\beta$ and the E-cadherin repressor, snail, in S18 and FTC133 cells. (D) Effect of $\mathrm{LiCl}$ on snail. $\mathrm{LiCl}(5 \mathrm{mM})$ increased the protein levels of snail in both S18 and FTC133 cells; C, control. 
a mechanistic role in E-cadherin dysregulation. Reciprocal co-immunoprecipitation experiments demonstrated a functional interaction between GSK-3 $\beta$ and snail (Fig. 3C). Treatment with $\mathrm{LiCl}(5 \mathrm{mM})$ significantly upregulated the E-cadherin repressor snail in normal and neoplastic thyrocytes (Fig. 3D). Thus, LiCl may destabilize the adherens junction by both snail upregulation and GSK-3 $\beta$ inhibition. Treatment with $\mathrm{LiCl}$ results in the nuclear translocation of $\beta$-catenin and enhanced TCF/LEF-dependent transcriptional activity.

Confocal analyses of the nuclear $\beta$-catenin expression of control and lithium-treated S18 thyroid cell lines revealed a relative increase in the nuclear $\beta$-catenin levels in a dose-dependent manner (data for dose-dependency not shown). In contrast to the control cells, in which $\beta$-catenin was primarily located in the membrane (Fig. 4A), $\beta$-catenin localization was predominantly nuclear in LiCl-treated S18 thyrocytes (Fig. 4B). To assess the $\beta$-catenin-driven TCF/LEF-dependent transcriptional activity, we further

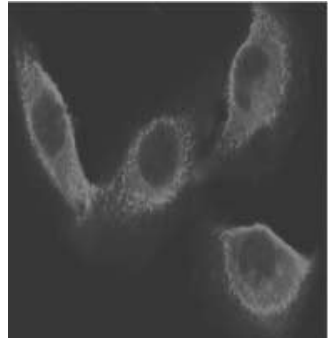

(A)

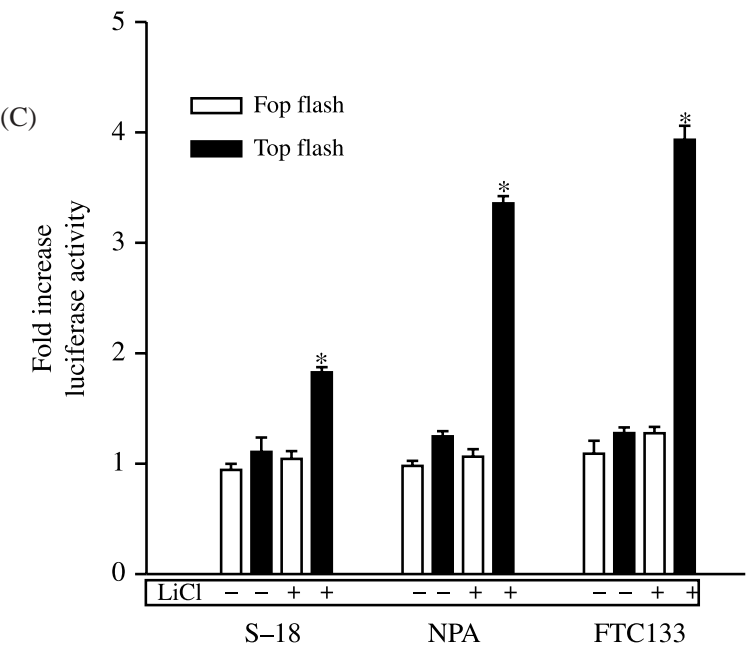

Figure 4 The effect of $\mathrm{LiCl}$ on the subcellular localization of $\beta$ catenin. Immunofluorescence and confocal analyses demonstrate a predominant membrane localization of $\beta$-catenin in control cells (A) whereas after $\mathrm{LiCl}(5 \mathrm{mM})$ treatment there is a predominant nuclear localization of $\beta$-catenin in $\mathrm{S} 18$ cells $(B)$. The effect of $\mathrm{LiCl}$ $(5 \mathrm{mM})$ on the $\beta$-catenin-driven TCF/LEF-dependent reportergene assay in normal (S18) and neoplastic thyrocytes (FTC133, NPA; C). The pair of columns on the left for any cell line represents control stimulation whereas the pair on the right represents $\mathrm{LiCl}$ stimulation. performed reporter-gene analysis with the TOP/FOP Flash reporter-gene assay. In cells co-transfected with the pTopflash luciferase reporter plasmid, $5 \mathrm{mM} \mathrm{LiCl}$ resulted in an increase in $\beta$-catenin-mediated transcriptional activation of TCF/LEF-responsive genes. At $5 \mathrm{mM} \mathrm{LiCl}$ induced 2-, 3- and 4-fold increases in luciferase activity in S18, NPA and FTC133 cells, respectively (Fig. 4C). This indicates that lithium stimulates Wnt/ $\beta$-catenin signalling by specifically activating TCF/LEF-dependent transcriptional activity.

\section{Effect of LiCl on proliferation of thyrocytes in vitro}

To test whether or not $\mathrm{LiCl}$ could act as the sole growth factor for thyrocyte proliferation in vitro, we studied serum-deprived normal and neoplastic thyrocytes in serum-free conditions with and without $\mathrm{LiCl}(5 \mathrm{mM})$. Lithium treatment dose-dependently significantly increased proliferation in all cells tested (S18, NPA, FTC133; Fig. 5). Thus it seems likely that inhibition of GSK-3 $\beta$ by lithium leads to an enhancement of the proliferative potency. To better delineate the signalling pathways involved we stably transfected FTC133 cells with dnTCF4 to block Wnt/ $\beta$-catenin signalling or with dnCREB to inhibit the TSH/cAMP/CREB cascade. Lithium-dependent stimulation of proliferation was still maintained in dnCREB-transfected cells but was reduced by approx. $50 \%$ in dnTCF4 transfected cells when compared with controls $(P<0.05$; Fig. 6).

\section{LiCl increases intranuclear cyclin D1 levels in thyroid cell lines}

This activation of the Wnt signalling pathway by $\mathrm{LiCl}$ was confirmed by measuring cyclin D1 expression, a

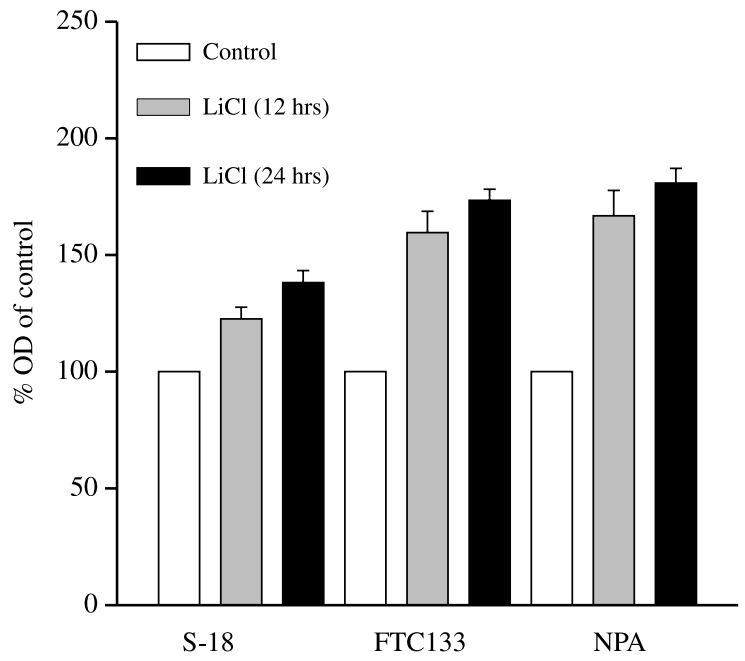

Figure $5\left[{ }^{3} \mathrm{H}\right]$ Thymidine-incorporation assay to show the effect of $\mathrm{LiCl}$ on the proliferation of normal (S18) and neoplastic (NPA, FTC133) thyrocytes after 12 and $24 \mathrm{~h}$ of $\mathrm{LiCl}(5 \mathrm{mM})$ treatment. 


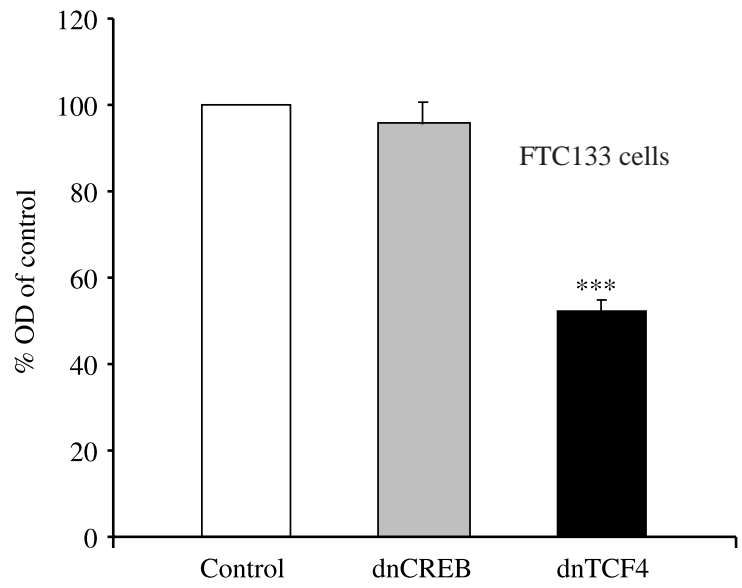

Figure $6\left[{ }^{3} \mathrm{H}\right]$ Thymidine-incorporation assay to show the specificity of the $\mathrm{LiCl}$-medicated effects on the proliferation of neoplastic thyrocytes by stable transfection of dnCREB and dnTCF4 in FTC133 cells.

known TCF/LEF target gene. Cyclin D1 expression in nuclear extracts of S18 and FTC133 cells with and without $\mathrm{LiCl}$ revealed a dose-dependent $(1-20 \mathrm{mM})$ increase in the nuclear cyclin D1 levels when analysed by immunoblot (Fig. 7A). This increased intranuclear cyclin D1 protein accumulation was further substantiated by confocal analysis of S18 (Fig. 7B and C) and FTC133 cells (Fig. 7D and E).

\section{Discussion}

The basic mechanisms involved in thyroid growth and proliferation in thyroid cancer are still incompletely characterized. Here we investigated the role of the canonical $W n t / \beta$-catenin signalling pathway and its interrelation with lithium effects on thyroid growth. Confirming previous reports that therapeutic concentrations of $\mathrm{LiCl}(1-5 \mathrm{mM})$ confer a sustained proliferative advantage to thyrocytes (3) we identified at least four sites of action for $W n t / \beta$-catenin-dependent lithium effects. First, LiCl inhibits GSK-3 $\beta$ via phosphorylation at Ser-9 and stabilizes the free form of the active $\beta$-catenin in a dose-dependent $(1-20 \mathrm{mM})$ and time-dependent $(0-24 \mathrm{~h})$ manner. Second, in LiCl-treated cells proliferation is significantly increased ( $\left[{ }^{3} \mathrm{H}\right]$ thymidine-incorporation assay), which appears to be mediated via nuclear translocation of stabilized $\beta$-catenin (reporter-gene assay) and upregulation of nuclear cyclin D1 levels. Third, E-cadherin expression is dose-dependently downregulated by lithium $(1-5 \mathrm{mM})$. Since GSK- $3 \beta$ physiologically regulates the intracellular levels of the E-cadherin repressor, snail, our data indicates that lithium-mediated GSK-3 $\beta$ inhibition secondarily induces snail upregulation and subsequently downregulates E-cadherin. Fourth, lithium inhibits the proteasomal degradation of $\beta$-catenin. Lithium effects on GSK-3 $\beta$ phosphorylation and activity are well characterized in other cell types $(23-25)$. GSK-3 $\beta$, a serine/threonine kinase, phosphorylates $\beta$-catenin (at Ser-33, Ser-37 and Thr-41) and leads to its ubiquitination and proteasomal degradation (27). Similarly, our immunoblot results show that in thyrocytes lithium dose- and time-dependently inhibits GSK-3 $\beta$ by Ser-9 phosphorylation and stabilizes free $\beta$-catenin in the cytoplasm. Indirect immunofluorescence and cell-fractionation studies further confirmed that free $\beta$-catenin actively translocates to the nucleus where $\beta$-catenin is transcriptionally active, as shown by several approaches. In a reporter-

(A)

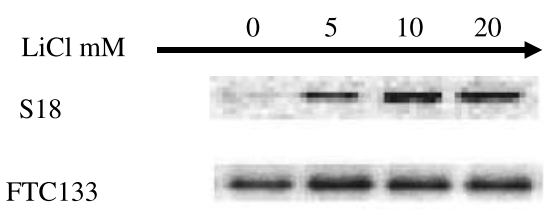

IB: Cyclin D1 mAb

Figure 7 Effect of $\mathrm{LiCl}$ on the expression of nuclear cyclin D1 levels. Immunoblot analyses revealed a dose-dependent increase in the nuclear cyclin D1 levels after $\mathrm{LiCl}$ treatment in both S18 and FTC133 cells (A). Further, immunofluorescence and confocal analyses demonstrated a strong nuclear signal for cyclin D1 (polyclonal rabbit antibody) in $5 \mathrm{mM} \mathrm{LiCl-trea-}$ ted $S 18$ cells $(B, C)$ and FTC133 cells $(D, E)$ as compared with untreated control cells. 
gene assay for $\beta$-catenin lithium specifically activated transcription and this is supported by measurements of known targets of $\beta$-catenin, such as cyclin D1 activation, or by testing for more general end-points, such as MTT or $\left[{ }^{3} \mathrm{H}\right]$ thymidine-incorporation assays. Thus, as previously described for other cellular systems $(25,27)$, inactivation of GSK-3 $\beta$ by lithium appears to induce thyrocyte proliferation. Furthermore, $\mathrm{LiCl}$ has a dose-dependent effect on the membrane expression of E-cadherin. Membrane-bound $\beta$-catenin could be co-immunoprecipitated with E-cadherin and lithium treatment significantly decreased the fraction of $\beta$-catenin bound to E-cadherin, indicating that lithium diminishes E-cadherin/ $\beta$-catenin binding and may downregulate E-cadherin in the membrane.

Because Zhou et al. (28) recently demonstrated a direct involvement of snail in E-cadherin downregulation we tested whether the E-cadherin gene repressor snail may be upregulated by lithium. GSK-3 $\beta$ binds to and phosphorylates snail at two consensus motifs to dually regulate the function and subcellular localization of this protein (28). Phosphorylation of the first motif regulates its $\beta$-Trcp-mediated ubiquitination, whereas phosphorylation of the second motif controls its subcellular localization. Upregulation of snail due to the inhibition of GSK-3 $\beta$ by lithium, as shown here for thyrocytes, is likely to serve as a mechanism for E-cadherin downregulation. Regardless of the mechanism, the resulting impairment of the cadherin-catenin complex at the adherens junction may contribute to the increased pool of free $\beta$-catenin that upon translocation to the nucleus may add to the activation of $\beta$-catenin target genes via TCF/LEF transcription.

Inhibition of the proteasome by lithium is a recently recognized phenomenon, although its clinical significance is unknown $(23,29)$. In our study the presence of phosphorylated $\beta$-catenin at high doses of lithium $(10-20 \mathrm{mM})$, where GSK-3 $\beta$ is inactivated, indicates altered $\beta$-catenin degradation. Since lithium inactivates GSK-3 $\beta$ in primary thyrocytes (S18) by more than $80 \%$ at concentrations between 10 and $20 \mathrm{mM}$, the presence of phosphorylated $\beta$-catenin at these doses of lithium $(10-20 \mathrm{mM})$ is unexpected. It may indicate interference with $\beta$-catenin degradation. Although the possibility that lithium might activate alternative pathways of $\beta$-catenin degradation cannot be ruled out, this finding substantiates the recently published data by Rice \& Sartorelli (23) showing that lithium exerts an inhibitory effect on the $20 \mathrm{~S}$ proteasome. Thus, from a conceptual point of view, it may be envisaged that the inhibition of the proteasome by lithium may lead to an accumulation of undegraded oncogenic proteins like $\beta$-catenin which may via nuclear translocation lead to a state of increased proliferation signals to the cell. Only scarce data are currently available on the functional interactions and regulation of nuclear phospho- $\beta$-catenin and its clinical implications. Tissue microarray-based analysis of melanoma samples by Kielhorn et al. (30), however, highlighted the fact that increased levels of nuclear phospho- $\beta$-catenin are associated with a decreased overall survival in these patients. This is supported by recent molecular studies in poorly differentiated and anaplastic carcinomas, which in contrast to well-differentiated tumours harbour $\beta$-catenin mutations with increased frequency $(31-33)$. Common belief suggests a dominant role for TSH/cAMP/CREB signalling in the control of thyrocyte proliferation $(4,34-37)$. Previously, Woloshin et al. (38), using the FRTL5 thyroid cell line as a model system, tested the relevance of the TSH/cAMP/CREB pathway by permanently transfecting an expression vector containing either the gene for wild-type CREB (wtCREB) or a dominant negative mutant form of CREB (dnCREB). Analyses of growth in the transfected clones revealed that transfection of wtCREB had no effect on thyroid growth in comparison with untransfected cells, whereas cells expressing dnCREB showed an 18-40\% reduction in TSH-stimulated growth (38). At a molecular level, lithium may affect thyroid cell function via its inhibitory action on the inositol 3-phosphate signalling pathway, cAMP function or ATPase activity (9, 39, 40). In addition, our data indicate that lithiummediated effects on thyroid cell functions may be due to the activation of $W n t / \beta$-catenin signalling.

Despite the suggestive effects of lithium on GSK-3 $\beta$ kinase activity $(\beta$-catenin nuclear translocation, gene expression of $\beta$-catenin-dependent genes/cyclin D1, cell proliferation), we tested further the specificity and importance of lithium's effect on Wnt/ $\beta$-catenin signalling. We blocked the TCF/LEF and CREB pathways by transfection of dnTCF4 and dnCREB constructs, respectively. FTC133 cells, stably transfected with dnTCF4 (to rule out activation of the $\beta$-catenin/TCF/LEF pathway), resulted in an approx. $50 \%$ decreased proliferation. On the other hand, transfection of dnCREB constructs (to rule out the activation of the TSH/PKA/CREB pathway) had no such effect. This effect was particularly evident following $24 \mathrm{~h}$ incubation with $\mathrm{LiCl}(5 \mathrm{mM})$ and indicates that LiCl-induced activation of $W n t / \beta$-catenin signalling may play an additional and independent role in the control of thyrocyte proliferation.

In summary, using $\mathrm{LiCl}$ as a tool to activate Wnt/ $\beta$-catenin signalling, we have shown the functional relevance of $W n t / \beta$-catenin signalling in the control of thyrocyte proliferation. In our study we have used doses of $\mathrm{LiCl}(1-5 \mathrm{mM})$ comparable to that used in the management and prophylaxis of bipolar psychiatric disorders. Since thyroid swelling and goitre formation are potential side effects of prolonged lithium therapy, we suggest that chronic lithium use may activate the Wnt/ $\beta$-catenin signalling in these patients, which in turn may contribute towards thyrocyte proliferation. Thus our results support a dominant role of Wnt/ 
$\beta$-catenin signalling relative to the TSH/PKA/CREB pathway in the proliferation control of normal and neoplastic thyrocytes.

\section{Acknowledgements}

This work was supported by Deutsche Krebshilfe.

\section{References}

1 Caykoylu A, Capoglu I, Unuvar N, Erdem F \& Cetinkaya R. Thyroid abnormalities in lithium-treated patients with bipolar affective disorder. Journal of Internal Medicine \& Research 2002 $3080-84$.

2 Ozpoyraz N, Tamam L \& Kulan E. Thyroid abnormalities in lithium-treated patients. Advanced Therapy 200219 176-184.

3 Gaberscek S, Kalisnik M, Pezdirc M, Pavlin K \& Hojker S. Influence of lithium on growth and viability of thyroid follicular cells. Folia Biologica (Praha) 200248 200-204.

4 Fuse M, Tanaka T, Shibata T, Yoshida T, Noguchi Y, Misawa N, Yasuda T, Saito Y, Kohn LD \& Tatsuno I. Regulation of geranylgeranyl pyrophosphate synthase in the proliferation of rat FRTL-5 cells: involvement of both cAMP-PKA and PI3-AKT pathways. Biochemical $\mathcal{E}$ Biophysical Research Communications 2004315 1147-1153.

5 Mincione G, Piccirelli A, Lazzereschi D, Salomon DS \& Colletta G. Heregulindependent autocrine loop regulates growth of K-ras but not erbB-2 transformed rat thyroid epithelial cells. Journal of Cell Physiology $1998176383-391$.

6 Postiglione MP, Parlato R, Rodriguez-Mallon A, Rosica A, Mithbaokar P, Maresca M, Marians RC, Davies TF, Zannini MS, De Felice M \& Di Lauro R. Role of the thyroid-stimulating hormone receptor signaling in development and differentiation of the thyroid gland. PNAS $20029915462-15467$.

7 Sheils OM \& Sweeney EC. TSH receptor status of thyroid neoplasms-TaqMan RTPCR analysis of archival material. Journal of Pathology 1999188 87-92.

8 Hedgepeth CM, Conrad LJ, Zhang J, Huang HC, Lee VM \& Klein PS. Activation of the Wnt signaling pathway: a molecular mechanism for lithium action. Developmental Biology 1997185 82-91.

9 Klein PS \& Melton DA. A molecular mechanism for the effect of lithium on development. PNAS 199693 8455-8459.

10 Kremenevskaja N, von Wasielewski R, Rao AS, Schofl C, Andersson T \& Brabant G. Wnt-5a has tumor suppressor activity in thyroid carcinoma. Oncogene 200524 2144-2154.

11 Helmbrecht K, Kispert A, von Wasielewski R \& Brabant G. Identification of a Wnt/beta-catenin signaling pathway in human thyroid cells. Endocrinology $20011425261-5266$.

12 de Melker AA, Desban N \& Duband JL. Cellular localization and signaling activity of beta-catenin in migrating neural crest cells. Developmental Dynamics 2004230 708-726.

13 Naito A, Iwase H, Kuzushima T, Nakamura T \& Kobayashi S. Clinical significance of E-cadherin expression in thyroid neoplasms. Journal of Surgical Oncology 200176 176-180.

14 Saldanha G, Ghura V, Potter L \& Fletcher A. Nuclear beta-catenin in basal cell carcinoma correlates with increased proliferation. British Journal of Dermatology 2004151 157-164.

15 Nakashima M, Meirmanov S, Naruke Y, Kondo H, Saenko V, Rogounovitch T, Shimizu-Yoshida Y, Takamura N, Namba H, Ito M, Abrosimov A, Lushnikov E, Roumiantsev P, Tsyb A, Yamashita S \& Sekine I. Cyclin D1 overexpression in thyroid tumours from a radio-contaminated area and its correlation with Pin 1 and aberrant beta-catenin expression. Journal of Pathology $2004202446-455$.

16 Natsume H, Sasaki S, Kitagawa M, Kashiwabara Y, Matsushita A, Nakano K, Nishiyama K, Nagayama K, Misawa H, Masuda H \& Nakamura H. Beta-catenin/Tcfl-mediated transactivation of cyclin
D1 promoter is negatively regulated by thyroid hormone. Biochemical \& Biophysical Research Communications 2003309 408-413.

17 Meirmanov S, Nakashima M, Kondo H, Matsufuji R, Takamura N, Ishigaki K, Ito M, Prouglo Y, Yamashita S \& Sekine I. Correlation of cytoplasmic beta-catenin and cyclin D1 overexpression during thyroid carcinogenesis around Semipalatinsk nuclear test site. Thyroid 200313 537-545.

18 Ishigaki K, Namba H, Nakashima M, Nakayama T, Mitsutake N, Hayashi T, Maeda S, Ichinose M, Kanematsu T \& Yamashita S. Aberrant localization of beta-catenin correlates with overexpression of its target gene in human papillary thyroid cancer. Journal of Clinical Endocrinology \& Metabolism 200287 3433-3440.

19 Gotoh J, Obata M, Yoshie M, Kasai S \& Ogawa K. Cyclin D1 overexpression correlates with beta-catenin activation, but not with H-ras mutations, and phosphorylation of Akt, GSK3 beta and ERK1/2 in mouse hepatic carcinogenesis. Carcinogenesis 2003 24 435-442.

20 von Wasielewski R, Rhein A, Werner M, Scheumann GF, Dralle H, Potter E, Brabant G \& Georgii A. Immunohistochemical detection of E-cadherin in differentiated thyroid carcinomas correlates with clinical outcome. Cancer Research 199757 2501-2507.

21 Huang SH, Wu JC, Chang KJ, Liaw KY \& Wang SM. Expression of the cadherincatenin complex in well-differentiated human thyroid neoplastic tissue. Thyroid 19999 1095-1103.

22 Park JW, Yeh MW, Wong MG, Lobo M, Hyun WC, Duh QY \& Clark $\mathrm{OH}$. The heat shock protein 90-binding geldanamycin inhibits cancer cell proliferation, down-regulates oncoproteins, and inhibits epidermal growth factor-induced invasion in thyroid cancer cell lines. Journal of Clinical Endocrinology \& Metabolism 200388 3346-3353.

23 Rice AM \& Sartorelli AC. Inhibition of $20 \mathrm{~S}$ and 26 S proteasome activity by lithium chloride: impact on the differentiation of leukemia cells by all-trans retinoic acid. Journal of Biological Chemistry $200127642722-42727$.

24 Beurel E, Kornprobst M, Blivet-Van Eggelpoel MJ, Ruiz-Ruiz C, Cadoret A, Capeau J \& Desbois-Mouthon C. GSK-3beta inhibition by lithium confers resistance to chemotherapy-induced apoptosis through the repression of CD95 (Fas/APO-1) expression. Experimental Cell Research $2004300354-364$.

25 Bhat RV, Budd Haeberlein SL \& Avila J. Glycogen synthase kinase 3: a drug target for CNS therapies. Journal of Neurochemistry 2004 $891313-1317$.

26 De Sarno P, Li X \& Jope RS. Regulation of Akt and glycogen synthase kinase-3 beta phosphorylation by sodium valproate and lithium. Neuropharmacology 200243 1158-1164.

27 Sadot E, Conacci-Sorrell M, Zhurinsky J, Shnizer D, Lando Z, Zharhary D, Kam Z, Ben-Ze'ev A \& Geiger B. Regulation of S33/S37 phosphorylated beta-catenin in normal and transformed cells. Journal of Cell Science $20021152771-2780$.

28 Zhou BP, Deng J, Xia W, Xu J, Li YM, Gunduz M \& Hung MC. Dual regulation of Snail by GSK-3beta-mediated phosphorylation in control of epithelial-mesenchymal transition. Nature Cell Biology $20046931-940$.

29 Holtz KM, Rice AM \& Sartorelli AC. Lithium chloride inactivates the $20 S$ proteasome from WEHI-3B D + leukemia cells. Biochemical $\mathcal{E}$ Biophysical Research Communications 2003303 1058-1064.

30 Kielhorn E, Provost E, Olsen D, D’Aquila TG, Smith BL, Camp RL \& Rimm DL. Tissue microarray-based analysis shows phospho-betacatenin expression in malignant melanoma is associated with poor outcome. International Journal of Cancer 2003103 652-656.

31 Garcia-Rostan G, Camp RL, Herrero A, Carcangiu ML, Rimm DL \& Tallini G. Betacatenin dysregulation in thyroid neoplasms: downregulation, aberrant nuclear expression, and CTNNB1 exon 3 mutations are markers for aggressive tumor phenotypes and poor prognosis. American Journal of Pathology 2001158 987-996.

32 Nakatani Y, Masudo K, Miyagi Y, Inayama Y, Kawano N, Tanaka Y, Kato K, Ito T, Kitamura H, Nagashima Y, Yamanaka S, Nakamura N, Sano J, Ogawa N, Ishiwa N, Notohara K, Resl M \& Mark EJ. Aberrant nuclear localization and gene mutation of beta-catenin in low-grade adenocarcinoma 
of fetal lung type: up-regulation of the Wnt signaling pathway may be a common denominator for the development of tumors that form morules. Modern Pathology 200215 617-624.

33 Nikiforov YE. Genetic alterations involved in the transition from well-differentiated to poorly differentiated and anaplastic thyroid carcinomas. Endocrine Pathology 200415 319-327.

34 Kimura T, Van Keymeulen A, Golstein J, Fusco A, Dumont JE \& Roger PP. Regulation of thyroid cell proliferation by TSH and other factors: a critical evaluation of in vitro models. Endocrine Reviews 200122 631-656.

35 Nguyen LQ, Kopp P, Martinson F, Stanfield K, Roth SI \& Jameson JL. A dominant negative CREB (cAMP response element-binding protein) isoform inhibits thyrocyte growth, thyroid-specific gene expression, differentiation, and function. Molecular Endocrinology 200014 1448-1461.

36 Uyttersprot N, Costagliola S, Dumont JE \& Miot F. Requirement for cAMP-response element (CRE) binding protein/CRE modulator transcription factors in thyrotropin-induced proliferation of dog thyroid cells in primary culture. European Journal of Biochemistry $1999259370-378$.
37 Vassart G \& Dumont JE. The thyrotropin receptor and the regulation of thyrocyte function and growth. Endocrine Reviews $199213596-611$.

38 Woloshin PI, Walton KM, Rehfuss RP, Goodman RH \& Cone RD. $3^{\prime}, 5^{\prime}$-cyclic adenosine monophosphate-regulated enhancer binding (CREB) activity is required for normal growth and differentiated phenotype in the FRTL5 thyroid follicular cell line. Molecular Endocrinology 19926 1725-1733.

39 Plyte SE, Hughes K, Nikolakaki E, Pulverer BJ \& Woodgett JR. Glycogen synthase kinase-3: functions in oncogenesis and development. Biochimica et Biophysica Acta 19921114 147-162.

40 Lazarus JH. The effects of lithium therapy on thyroid and thyrotropin-releasing hormone. Thyroid 19988 909-913.

Received 24 May 2005

Accepted 1 September 2005 